\title{
Measurements of the acid-binding capacity of ingredients used in pig diets
}

\author{
Peadar G. Lawlor', P. Brendan Lynch', Patrick J. Caffrey², James J. O'Reilly' and M. Karen O'Connell' \\ ' Pig Production Department, Teagasc, Moorepark Research Centre, Fermoy, Co. Cork, Ireland \\ ${ }^{2}$ Department of Animal Science and Production, Faculty of Agriculture, University College, Dublin, Ireland.
}

Some feed ingredients bind more acid in the stomach than others and for this reason may be best omitted Key words: from pig starter foods if gastric acidity is to be promoted. The objective of this study was to measure the Pig, acid-binding capacity (ABC) of ingredients commonly used in pig starter foods. Ingredients were categorised Diet, as follows: (i) milk products $(n=6)$, (ii) cereals $(n=10)$, (iii) root and pulp products $(n=5)$, (iv) vegetable Ingredients, proteins $(n=11),(v)$ meat and fish meal $(n=2)$, (vi) medication $(n=3)$, (vii) amino acids $(n=4)$, (viii) Acid-binding capacity. minerals $(n=16)$, (ix) acid salts $(n=4),(x)$ acids $(n=10)$. A 0.5g sample of food was suspended in $50 \mathrm{ml}$ distilled de-ionised water with continuous stirring. This suspension was titrated with $0.1 \mathrm{~mol} / \mathrm{L} \mathrm{HCl}$ or 0.1 $\mathrm{mol} / \mathrm{L} \mathrm{NaOH}$ so that approximately 10 additions of titrant was required to reach $\mathrm{pH}$ 3.0. The $\mathrm{pH}$ readings after each addition were recorded following equilibration for three minutes. $A B C$ was calculated as the amount of acid in milliequivalents (meq) required to lower the $\mathrm{pH}$ of $\mathrm{I} \mathrm{kg}$ food to (a) $\mathrm{pH} 4.0$ (ABC-4) and (b) $\mathrm{pH} 3.0$ (ABC-3). Categories of food had significantly different $(\mathrm{P}<0.0 \mathrm{I}) \mathrm{ABC}$ values. Mean $\mathrm{ABC}-4$ and ABC-3 values of the ten categories were: (i) 623 (s.d. 367.0) and 936 (s.d. 460.2), (ii) 142 (s.d. 79.2) and 324 (s.d. 146.4), (iii) 368 (s.d. 65.3) and 804 (s.d. 126.7), (iv) 38 I (s.d. I86.l) and 746 (s.d. 227.0), (v) 749 (s.d. 21 I.6) and 1508 (s.d. 360.8), (vi) 120 (s.d. 95.6) and 26। (s.d. I63.2), (vii) 177 (s.d. 60.7) and 1078 (s.d. 359.0), (viii) 5064 (s.d. 5525. I) and 705 I (s.d. 59I I.6), (ix) 5057 (s.d. I336.6) and 8945 (s.d. 2654.I) and (x) -5883 (s.d. 4220.5) and -259I (s.d. 2245.4) meq HCl per kg, respectively. Within category, ABC-3 and ABC4 values were highly correlated: $R^{2}$ values of 0.80 and greater for food categories i, iv, v, vi, vii and viii. The correlation between predicted and observed $A B C$ values of 34 mixed diets was 0.83 for ABC-4 and 0.7 I for $A B C$-3. It was concluded that complete diets with low $A B C$ values may be formulated through careful selection of ingredients. The final $\mathrm{pH}$ to which $A B C$ is measured should matter little as $A B C-3$ and $A B C-4$ are highly correlated.

\section{Introduction}

In the pig, protein digestion begins in the stomach with the action of pepsins, secreted as the enzyme precursors - pepsinogens - by stomach mucosa. Conversion of pepsinogen to pepsin occurs rapidly at $\mathrm{pH} 2.0$ but only slowly at $\mathrm{pH} 5.0$ to 6.0. In turn, pepsins work best in an acidic environment, $\mathrm{pH} 2.0$ to 3.5 , and activity declines rapidly above this $\mathrm{pH}$. Carbohydrate hydrolysis in the stomach occurs by the action of salivary amylase, which, in contrast to pepsin, is inactivated once $\mathrm{pH}$ falls to 3.5 (Kidder and Manners, 1978; Longland, 1991; Yen $2001)$.

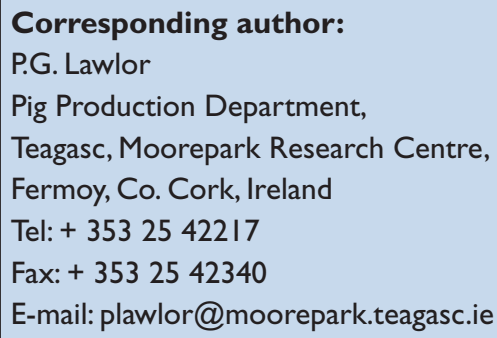

In the suckling pig, acid secretion is low and the principal source of acidity is bacterial fermentation of lactose from sows milk to lactic acid (Cranwell et al., 1968, 1976; Kidder and Manners, 1978). A high level of lactate in the stomach tends to inhibit $\mathrm{HCl}$ secretion (Cranwell et al., 1976; Yen, 200I). Ingestion of solid feed reduces the level of lactic acid in the stomach (Yen, 200I) and stimulates $\mathrm{HCl}$ production (Cranwell et al., 1976; Cranwell, 1985) but, in practice, creep feed consumption is low and variable at least up to four weeks of age (Lawlor et al., 2002).

At weaning, a combination of low acid secretion, lack of lactose substrate, and consumption of large meals at infrequent intervals can result in elevated $\mathrm{pH}$, often to over 5.0 and it may remain high for several days (Kidder and Manners, 1978). The high acid-binding/ buffering capacity of the feed (its ability to neutralise feed acid) helps to further raise the stomach $\mathrm{pH}$ (Prohaszka and Baron, 1980; Jasaitis et al., 1987; Bolduan et al., 1988). Inclusion of whey or lactose in the starter diet ensures continuation of bacterial fermentation and some, though reduced, lactic acid production (Kidder and Manners, 1978; Easter, 1988). Development of $\mathrm{HCl}$ secretory capacity occurs more rapidly in the weaned pig than in the suckling pig (Cranwell and Moughan, 1989). 


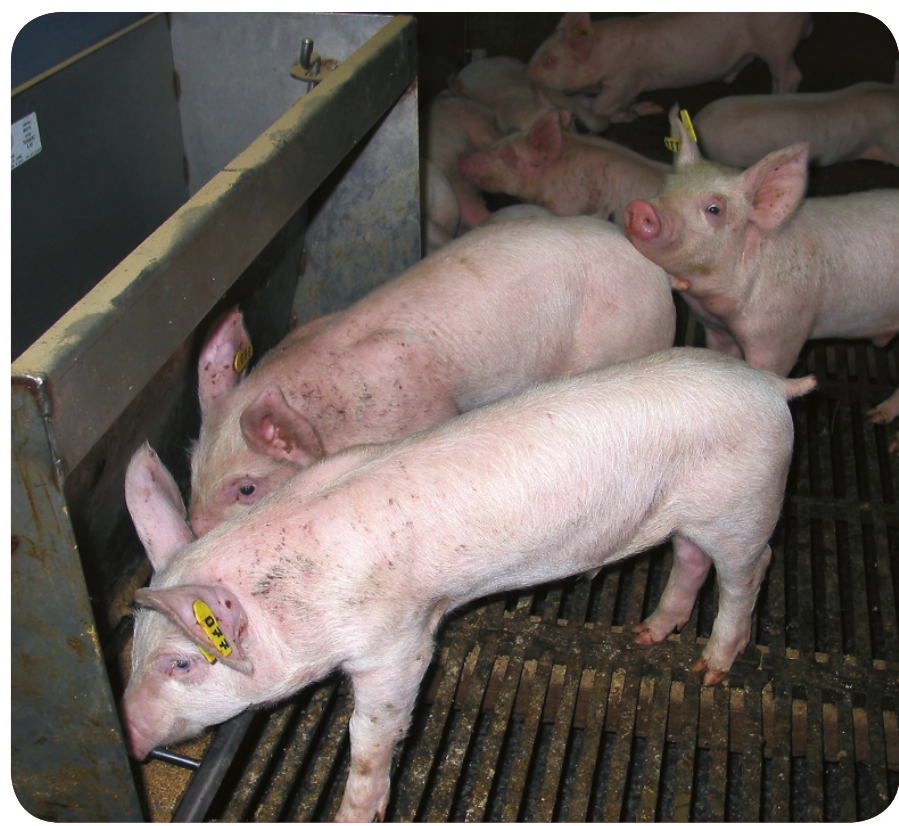

Lowering the acid-binding capacity of diets for newly-weaned pigs can help ease the transition from milk to solid food at weaning.

Raised stomach $\mathrm{pH}$ after weaning results in reduced digestion of feed which will then be fermented in the hind gut and may provoke diarrhoea. A high gastric $\mathrm{pH}$ will also allow pathogens to survive and allow them greater opportunity to colonise the digestive tract (Bolduan et al., 1988; Yen, 200I).

The concept of manipulating stomach acidity by adding acid to feeds or using feeds of low acid-binding or buffering capacity (Prohaszka and Baron, 1980; Jasaitis et al., 1987; Bolduan et al., 1988; Lawlor et al., 2005a; Lawlor et al., 2005b) has been around for a long time and addition of organic acids to piglet starter feeds is a common practice. However, there is little information on the acid-binding capacity $(A B C)$ of ingredients that are used in formulation of complete feeds. The limited published sets of data have been compiled using methods with different titration-end points (e.g., $\mathrm{pH}=3.0 \mathrm{or} \mathrm{pH}=4.0$ ) so that values are not comparable (Prohaszka and Baron, 1980; Jasaitis et al., 1987; Bolduan et al., 1988; Giger-Reverdin et al., 2002).

The objective of this study was to find the $A B C$ and buffering capacity values of individual feed ingredients and ingredient categories and to find if a correlation exists between $A B C-3$ and $A B C-4$ values. A further objective was to investigate the possibility of formulating complete diets of low $A B C$ for weaned pigs by using the $A B C$ values of each ingredient in the formulation matrix.

\section{Materials and methods}

Procedures

Ingredients commonly used in pig rations were obtained over a number of years from various commercial sources in Ireland. All ingredients (as received) were ground through a $2 \mathrm{~mm}$ screen using a laboratory hammer mill (Christy and Norris, Scunthorpe, UK), and were stored in air-tight jars at room temperature until analysis. Measurements were completed within one month of receiving each sample. Ingredients were grouped under the following headings for ease of analysis: (i) milk products, (ii) cereals, (iii) root and pulp products, (iv) vegetable proteins, (v) meat and fish meal, (vi) medication, (vii) amino acids, (viii) minerals, (ix) acid salts, and (x) acids. A modification of the procedure of Jasaitis et al. (1987) was used to determine $\mathrm{pH}$ and acid-binding capacity $(\mathrm{ABC})$. The latter procedure used only $\mathrm{pH}=4.0$ as the titration endpoint whereas the present study used $\mathrm{pH}=3.0$ as well as $\mathrm{pH}=4.0$ as titration endpoints in an effort to provide measures of greater relevance to pig nutrition. All $\mathrm{pH}$ measurements were made using a laboratory $\mathrm{pH}$ meter (PHM 220, Radiometer, Copenhagen) which was calibrated using certified $\mathrm{pH}=4.0$ and $\mathrm{pH}=7.0$ buffer solutions (Radiometer, Copenhagen). A $0.5 \mathrm{~g}$ sample of ingredient/feed was suspended in $50 \mathrm{ml}$ of distilled and de-ionised water and continuously stirred with a magnetic stirrer. Titrations were performed by addition of acid $(0.1 \mathrm{~N} \mathrm{HCl})$ in variable increments $(0.1$ to $10 \mathrm{ml}$ depending on the ingredient type and the stage of titration). Acid was added so that it would take approximately 10 separate additions of acid to reach $\mathrm{pH}$ 3.0. Initial $\mathrm{pH}$ and all further readings taken during the titration were recorded after equilibration for three minutes. $A B C$ was calculated as the amount of acid in milliequivalents (meq) required to lower the $\mathrm{pH}$ of $\mathrm{Ikg}$ of sample to (a) $\mathrm{pH} 4.0$ (ABC-4) and (b) $\mathrm{pH} 3.0(\mathrm{ABC}-3)$. The buffering capacity (BUF) was calculated by dividing the $A B C$ by the total change in $\mathrm{pH}$ units [from initial $\mathrm{pH}$ to the final $\mathrm{pH}$ of (a) 4.0 (BUF-4) and (b) 3.0 (BUF-3)]. BUF expresses the amount of acid required to produce a unit change in the $\mathrm{pH}$ of a feed ingredient / feed sample.

Feeds/ingredients with a $\mathrm{pH}$ less than 3 or 4 were titrated as above but against $0.1 \mathrm{~N} \mathrm{NaOH}$ until $\mathrm{pH} 4.0$ and/or $\mathrm{pH} 3.0$ was reached. $A B C$ and $\mathrm{BUF}$ values in these cases were given negative values.

\section{Statistical analysis}

The means and standard deviation for each ingredient were calculated for $\mathrm{pH}, \mathrm{ABC}-4, \mathrm{ABC}-3, \mathrm{BUF}-4$ and BUF-3. Regression equations (Proc Reg of Sas Inc., Cary, North Carolina) were established relating ABC3 to $A B C-4$ for the ingredients within each category. This procedure was also used to establish the relationship between the predicted and observed $A B C-4$ and $A B C-3$ values for 34 mixed pig diets. Predicted values were obtained by including the $A B C-4$ and $A B C-3$ values of each individual ingredient in the formulation matrix for the mixed diet.

\section{Results}

The mean $A B C$ and $B U F$ values for each ingredient are shown in Table I. The mean $A B C$ of each category and the correlation between $A B C-3$ and $A B C-4$ values for each category are shown in Table 2. The correlation between predicted and observed $A B C$ values for 34 post-weaning diets is presented in Table 3.

Initial $\mathrm{pH}, \mathrm{ABC}-4$ and $\mathrm{ABC}-3$ varied greatly between individual ingredients. Categories of ingredients were statistically different $(P<0.0 \mathrm{I})$ with regard to $A B C$ and $B U F$ values but great variation was also found within ingredient categories for initial $\mathrm{pH}, \mathrm{ABC}$ and $\mathrm{BUF}$.

Acid salts and minerals were the categories that had the highest $A B C$ and BUF values. Great variation occurred between the different mineral types. Zinc oxide, limestone flour and sodium bicarbonate had the highest $A B C$ values. Of the phosphorus sources, defluorinated phosphate had the highest $A B C$ values, dicalcium phosphate and mono dicalcium phosphate had intermediate values, while monammonium phosphate had the lowest values. Meat and fish meal, milk products, amino acids, root and pulp products and vegetable proteins were the categories of organic ingredients with the highest $A B C$ and BUF values. Cereals had the lowest values of the organic ingredient 
TABLE I: pH, acid-binding capacity (ABC) and buffering capacity (BUF) of some commonly used feed ingredients (mean \pm s.d.)

\begin{tabular}{|c|}
\hline Ingredient \\
\hline $\begin{array}{l}\text { Milk } \\
\text { Acid casein } \\
\text { Sows milk } \\
\text { Whey powder } \\
\text { Milk replacer } \\
\text { Skim milk } \\
\text { Rennet casein }\end{array}$ \\
\hline $\begin{array}{l}\text { Cereals } \\
\text { Oat flakes } \\
\text { Wheat } \\
\text { Pin head oats } \\
\text { Barley screenings } \\
\text { Maize starch } \\
\text { Maize } \\
\text { Barley } \\
\text { Flaked maize } \\
\text { Corn distillers } \\
\text { Pollard }\end{array}$ \\
\hline $\begin{array}{l}\text { Root and pulp products } \\
\text { Sugar } \\
\text { Cassava } \\
\text { Beet pulp } \\
\text { Molasses } \\
\text { Citrus pulp }\end{array}$ \\
\hline $\begin{array}{l}\text { Vegetable protein } \\
\text { Milo distillers } \\
\text { Beans } \\
\text { Palm kernal } \\
\text { Peas } \\
\text { Lupins } \\
\text { Maize gluten } \\
\text { Full fat soya } \\
\text { Sunflower meal } \\
\text { Sycomil } \\
\text { Rapeseed meal } \\
\text { Soybean meal }\end{array}$ \\
\hline $\begin{array}{l}\text { Meat and fishmeal } \\
\text { Meat and bone meal } \\
\text { Fishmeal }\end{array}$ \\
\hline $\begin{array}{l}\text { Fat } \\
\text { Fat } \\
\text { Fat blend }\end{array}$ \\
\hline $\begin{array}{l}\text { Medication } \\
\text { Spiratet } \\
\text { Choline chloride } \\
\text { Tylamix }\end{array}$ \\
\hline $\begin{array}{l}\text { Microbial protein } \\
\text { Yeast }\end{array}$ \\
\hline $\begin{array}{l}\text { Amino acids } \\
\text { Lysine } \\
\text { Tryptophan } \\
\text { Methionine } \\
\text { Threonine }\end{array}$ \\
\hline $\begin{array}{l}\text { Minerals } \\
\text { Ferrous sulphate } \\
\text { Salt } \\
\text { Copper sulphate } \\
\text { Cobalt sulphate } \\
\text { Monammonium phosphate } \\
\text { Ferrous oxide } \\
\text { Mould curb } \\
\text { Finisher minerals and vitamins } \\
\text { Weaner minerals and vitamins } \\
\text { Dicalcium phosphate } \\
\text { Sow minerals and vitamins } \\
\text { Potassium citrate } \\
\text { Mono dicalcium phosphate } \\
\text { Sodium citrate } \\
\text { Defluorinated phosphate } \\
\text { Calcium formate } \\
\text { Manganese oxide }\end{array}$ \\
\hline
\end{tabular}

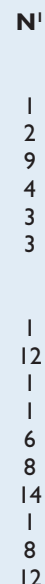

$\mathrm{pH}^{2}$

3.9

$8.1 \pm 0.04$

$6.6 \pm 0.31$

$6.7 \pm 0.22$

$7.1 \pm 0.20$

$8.1 \pm 0.06$

6.7

$6.9 \pm 0.12$
5.5

5.5
6.7

$7.0 \pm 0.78$

$6.7 \pm 0.24$

$6.6 \pm 0.18$

7.6

$4.4 \pm 0.17$

$6.9 \pm 0.29$

$5.8 \pm 0.06$

5.5
6.0

$6.1+0.08$

$6.1 \pm 0.08$
$6.8 \pm 0.08$

4.1
6.8

$5.9 \pm 0.10$

$6.8 \pm 0.11$

6.2

$4.4 \pm 0.07$

$6.9 \pm 0.28$

$6.7 \pm 0.19$

7.5

$6.3 \pm 0.11$

$7.1 \pm 0.06$

$1 \quad 6.6$

6.6
$6.7 \pm 0.37$

4.9
6.6

5.6

$6.7 \pm 0.52$
7.0

3.4

$6.5 \pm 0.38$

$7.0 \pm 0.23$

$6.5 \pm 0.34$

$6.5 \pm 0.22$

$3.2 \pm 0.09$

$7.5 \pm 0.18$

$5.1 \pm 0.06$

$7.4 \pm 0.04$

$4.2 \pm 0.05$

$8.7 \pm 0.16$

5.3

$5.2 \pm 0.04$

$5.2 \pm 0.03$

$7.6 \pm 0.19$

$5.3 \pm 0.05$

$8.6 \pm 0.07$

$4.4 \pm 0.26$

$8.4 \pm 0.19$

$9.9 \pm 0.09$

$7.4 \pm 0.15$

$8.8 \pm 0.07$
ABC $-4^{3}$

0

$48 I \pm 1.0$

$434 \pm 99.9$

$579 \pm 54.6$

$756 \pm 59.6$

$1423 \pm 35.5$

72
$108 \pm 14.9$

81
104

$91 \pm 45.6$

$91 \pm 45.6$
$111 \pm 35.8$

$113 \pm 14.3$

240

$96 \pm 38.6$

$292 \pm 20.6$

$23 \pm 8.4$

167
191

$399 \pm 37.6$

$373 \pm 25.4$

14
275

$250 \pm 38.2$

$278 \pm 24.0$

337

$114 \pm 19.7$

$480 \pm 43.5$

$482 \pm 52.7$

622
$498 \pm 49.3$

$642 \pm 51.1$

595

$738 \pm 219.3$

16
363

114

$101 \pm 68.6$

370

150

$123 \pm 23.3$

$179 \pm 17.1$

$192 \pm 75.9$

$218 \pm 57.6$

$-655 \pm 18.1$

$83 \pm 21.5$

$83 \pm 21.5$
$92+3.3$

$329 \pm 6.5$

$46 \pm 10.5$

$549 \pm 78.5$

2517

$3357 \pm 305.5$

$4292 \pm 1008.9$

$3098 \pm 1028.5$

$5413 \pm 216.4$

$5703 \pm 1.6$

$291 \pm 159.5$

$6334 \pm 13.6$

$6412 \pm 1032.9$

$3983 \pm 97.9$

$6678 \pm 1045.7$
ABC $-3^{4}$

BUF $-4^{5}$

BUF-3 ${ }^{6}$

200

$650 \pm 70.7$

$714 \pm 149.3$

$892 \pm 97.8$

$1105 \pm 108.7$

$1929 \pm 76.9$

180

$194 \pm 15.8$
239

240

$202 \pm 58.5$

$254 \pm 53.1$

$266 \pm 43$. 1

424

$438 \pm 42.9$

$572 \pm 24.0$

$98 \pm 11.8$

393
480

$790 \pm 45.5$

$790 \pm 45.5$
$873 \pm 49.9$

276
473

$485 \pm 51.5$

$515 \pm 43.1$

645

$571 \pm 79.4$

$823 \pm 62.2$

$852 \pm 91.4$

$945 \pm 65.2$

$1068 \pm 74.0$

920

$1457 \pm 334.5$

$85 \pm 96.8$

$118 \pm 0.8$

$168 \pm 36.5$

$214 \pm 38$. 1

$242 \pm 29.4$

$348 \pm 4.0$

27
$37 \pm 5.0$

56
39

$29 \pm 11.4$

$41 \pm 10.6$

$43 \pm 3.6$

67
$62 \pm 75.4$

$100 \pm 12$. 1

$13 \pm 5.2$
110

98

$190 \pm 19.1$

$135 \pm 8.1$

174
98

$132 \pm 23.2$

$98 \pm 9.8$
156

156
$334 \pm 73.1$

$166 \pm 13.9$

$180 \pm 14.7$

180

$215 \pm 20.5$

$210 \pm 18.0$

214

17

138

73

340

$226 \pm 136.0$

$37 \pm 23.5$

123

$-250$

$50 \pm 6.0$

$60 \pm 4.6$

$77 \pm 23.0$

$86 \pm 17.2$

$-821 \pm 77.3$

$24 \pm 6.8$

$80 \pm 7$.

$97 \pm 3.0$

$247 \pm 13.2$

$117 \pm 15.8$

2014

$2772 \pm 194.7$

$3472 \pm 765.1$

$857 \pm 293.7$

$4182 \pm 300.5$

$1251 \pm 19.0$

$1302 \pm 980.8$

$1449+66.9$

$1085 \pm 161.0$

$1182 \pm 29.6$

$1400 \pm 210.9$
222

$128 \pm 14.8$

$199 \pm 39.9$

$240 \pm 40.6$

$268 \pm 35.4$

$379 \pm 11.1$

49

$50 \pm 3.7$
97

65

$51 \pm 13.5$

$68 \pm 11.1$

$73 \pm 10.5$

92

$317 \pm 56.3$

$146 \pm 14.7$

$36 \pm 3.5$

156
163

$255 \pm 16.9$

$232 \pm 12.2$

256
125

$167 \pm 20.2$

$134 \pm 12.7$

204

$424 \pm 71.4$

$212 \pm 16.8$

$231 \pm 16.4$

216

$284 \pm 21.2$

$263 \pm 20.2$

243

$404 \pm 105.9$

72

168

133

$61 \pm 35.8$
152

325

$200 \pm 22.5$

$258 \pm 25.4$

$349 \pm 52.5$

$391 \pm 83.4$

$456 \pm 96.2$

$36 \pm 9.1$

$125 \pm 0.6$

$117 \pm 1.5$

$687 \pm 33.8$

$173 \pm 12.5$
1538

$2317 \pm 104.8$

$2819 \pm 448.8$

$1234 \pm 431.2$

$3268 \pm 117.1$

$1412 \pm 19.1$

$4400 \pm 2564.3$

$1628 \pm 58.6$

$1511 \pm 28.9$

$2760 \pm 18.3$

$1887 \pm 381.9$ 


\begin{tabular}{|c|c|c|c|c|c|c|}
\hline Sodium bicarbonate & 3 & $8.7 \pm 0.44$ & $12566 \pm 554.1$ & $12870 \pm 399.1$ & $2706 \pm 147.4$ & $2280 \pm 110.3$ \\
\hline Limestone flour & 13 & $8.9 \pm 0.46$ & $12932 \pm 21883$ & $|5044 \pm 2| 25.4$ & $2661 \pm 479.8$ & $2565 \pm 380.6$ \\
\hline Zinc oxide & 3 & $8.3 \pm 0.19$ & $|6321 \pm| 170 \mid$ & $17908 \pm 1100.9$ & $3768 \pm 193.0$ & $3363 \pm 238.0$ \\
\hline \multicolumn{7}{|l|}{ Acid } \\
\hline Orthophosphoric acid & 3 & $1.6 \pm 0.02$ & $-8858 \pm 168.2$ & $-7957 \pm 204.5$ & $-3665 \pm 54.5$ & $-5616 \pm 97.4$ \\
\hline Fumaric acid & 3 & $2.3 \pm 0.06$ & $-10862 \pm 469.6$ & $-4093 \pm 669.7$ & $-6314 \pm 54.6$ & $-5659 \pm 478.7$ \\
\hline Formic acid & 3 & $2.3 \pm 0.03$ & $-13550 \pm 765.0$ & $-3473 \pm 110.3$ & $-7824 \pm 572.9$ & $-4745 \pm 344.7$ \\
\hline Citric acid & 5 & $2.2 \pm 0.03$ & $-5605 \pm 202.2$ & $-2349 \pm 164.3$ & $-3156 \pm 89.9$ & $-3024 \pm 97.5$ \\
\hline Ascorbic acid & 3 & $2.8 \pm 0.03$ & $-217 \pm 28.6$ & $-2249 \pm 77.0$ & $-177 \pm 19.4$ & $-10159 \pm 1048$ \\
\hline Malic acid & 3 & $2.2 \pm 0.15$ & $-7214 \pm 694.6$ & $-2550 \pm 769.0$ & $-4084 \pm 575.8$ & $-3242 \pm 333.0$ \\
\hline Lactic acid & 3 & $2.4 \pm 0.02$ & $-5079 \pm 53.9$ & $-1498 \pm 23.7$ & $-3129 \pm 63.0$ & $-2405 \pm 111.3$ \\
\hline Acetic acid & 3 & $2.9 \pm 0.02$ & $-2283 \pm 104.1$ & $-|4| \pm 24.9$ & $-2011 \pm 133.1$ & $-103 \mid \pm 33.6$ \\
\hline Propionic acid & 3 & $3.0 \pm 0.01$ & $-1358 \pm 276.5$ & $-5 \pm 8.2$ & $-1348 \pm 259.6$ & $-238 \pm 4 \mid 2.4$ \\
\hline Sorbic acid & 1 & 3.5 & -220 & 120 & -400 & 267 \\
\hline
\end{tabular}

categories. Of the ingredients, both inorganic and organic, the acids category had the lowest $A B C$ and $B U F$ values. Most $A B C$ values for the individual acids were negative with orthophosphoric, fumaric, formic, malic and citric acids having the most negative values.

The mean $A B C-3$ and $A B C-4$ values for ingredients within categories are well correlated. $R^{2}$ values of 0.90 or greater were found for milk products and medication. $R^{2}$ values of between 0.85 and 0.90 were found for amino acids and minerals. Both vegetable proteins and meat and fishmeal had $R^{2}$ values of between 0.80 and 0.85 .

The $A B C$ values for mixed pig starter diets were predicted from the mean $A B C$ value (Table I) of each ingredient in their formulation and their composition in the diet. The correlation between predicted and observed $A B C$ values was relatively good. For $A B C-4, R^{2}$ was 0.83 and for $A B C-3$ the $R^{2}$ was 0.71 .

\section{Discussion}

Some ingredients bind more acid in the stomach than others and for this reason their use in pig starter diets might result in a high gastric $\mathrm{pH}$. A high gastric $\mathrm{pH}$ is detrimental to the pig because it allows the proliferation of deleterious micro-organisms (Bolduan et al., 1988) and inhibits protein digestion (Kidder and Manners, 1978; Longland, 1991; Yen, 200I).

In the present study, a range of ingredients that are commonly used in pig diets was examined. It was thought that ingredients of low $A B C$ would be identified which could then be used to formulate a starter diet in such a way that gastric acidity would be promoted. Jasaitis et al. (1987) found that mineral additives had higher ABC-4 and BUF-4 values than organic ingredients. In the present experiment, minerals as an ingredient category had the second highest $A B C$ and $B U F$ values of all categories examined. Acid salts were found to have the highest values. Jasaitis et al. (1987) found that carbonates and dibasic or tribasic mineral additives had the highest $A B C$ and BUF values. With the exception of the trace minerals zinc oxide and manganese oxide, the present experiment agrees with this finding. Limestone flour and

\begin{tabular}{|c|c|c|c|c|c|c|c|c|c|}
\hline Feed type & $\mathbf{N}^{\prime}$ & ABC-4 & ABC-3 & $\mathbf{Y}^{2}$ & $\mathbf{A}^{3}$ & $B^{4}$ & $\left(R^{2}\right)^{5}$ & $\left(\operatorname{Adj} . R^{2}\right)^{6}$ & $\mathbf{R S D}^{7}$ \\
\hline Milk & 22 & $623 \pm 367.0$ & $936 \pm 460.2$ & $A B C-4$ & $-118.45^{* * * *}$ & $0.79 * * *$ & 0.99 & 0.99 & 39.55 \\
\hline Cereals & 64 & $142 \pm 79.2$ & $324 \pm 146.4$ & $A B C-4$ & -2.34 & $0.45^{* * * *}$ & 0.68 & 0.67 & 45.41 \\
\hline Root and pulp products & 27 & $368 \pm 65.3$ & $804.7 \pm 126.7$ & $A B C-4$ & 14.50 & $0.44^{* * * *}$ & 0.73 & 0.72 & 34.75 \\
\hline Vegetable proteins & 84 & $380.7 \pm 186.1$ & $746 \pm 227.0$ & $A B C-4$ & $-177.57^{* * * *}$ & $0.75^{* * * *}$ & 0.83 & 0.83 & 76.49 \\
\hline Meat and fishmeal & 11 & $749 \pm 211.6$ & $1508 \pm 360.8$ & $A B C-4$ & -56.66 & $0.53^{* * * * *}$ & 0.83 & 0.81 & 91.75 \\
\hline Amino acids & 39 & $177 \pm 60.7$ & $1078 \pm 359.0$ & $A B C-4$ & 7.40 & $0.16^{* * * *}$ & 0.87 & 0.86 & 22.51 \\
\hline Minerals & 73 & $5064 \pm 5525.1$ & $7051 \pm 5911.6$ & $A B C-4$ & $-1157.30 * * *$ & $0.88^{* * * *}$ & 0.89 & 0.89 & 1833.53 \\
\hline Acid salt & 10 & $5057 \pm 1336.6$ & $8945 \pm 2654$ & $A B C-4$ & $4909.16 *$ & 0.02 & 0.01 & -0.12 & 1416.90 \\
\hline Acid & 30 & $-5883 \pm 4220.5$ & $-2591 \pm 2245.4$ & $A B C-4$ & $-277|.4|^{* *}$ & $1.20 * * *$ & 0.41 & 0.39 & 3304.56 \\
\hline
\end{tabular}

Table 3: Models for predicting observed acid-binding capacity to $\mathrm{pH} 4.0(\mathrm{ABC}-4)$ and observed acid-binding capacity to $\mathrm{pH} 3.0(\mathrm{ABC}-3)$ from their respective predicted $A B C$ values

$\begin{array}{lccccccccc}\text { Measure } & \mathbf{N}^{1} & \begin{array}{c}\text { Observed } \\ \text { value }\end{array} & \begin{array}{c}\text { Predicted } \\ \text { value }\end{array} & \mathbf{Y}^{2} & \mathbf{A}^{3} & \mathbf{B}^{4} & \left.\mathbf{( R}^{2}\right)^{5} & \left.\text { (Adj. R}^{2}\right)^{6} & \mathbf{R S D}^{7} \\ \text { ABC-4 } & 34 & 259 \pm 93.3 & 294 \pm 124.8 & \text { Observed ABC-4 } & 59.50^{* *} & 0.68^{* * * *} & 0.83 & 0.82 & 39.11 \\ \text { ABC-3 } & 34 & 608 \pm 88.8 & 640 \pm 77.6 & \text { Observed ABC-3 } & -9.32 & 0.97 * * * & 0.71 & 0.70 & 48.28\end{array}$

'Number of samples. ${ }^{2}$ Dependent variable. ${ }^{3}$ Regression constant. ${ }^{4}$ Regression coefficient for regression on predicted $\mathrm{ABC}-4$ or $\mathrm{ABC}-3$ value. ${ }^{5} \mathrm{Coefficient}$ of determination. ${ }^{6} \mathrm{Adjusted} \mathrm{R}^{2}$. ${ }^{7}$ Residual standard deviation. 
sodium bicarbonate had the highest $A B C$ values with defluorinated phosphate, dicalcium phosphate and mono dicalcium phosphate being the minerals with the next highest values. Bolduan (1988) found that increasing the mineral supplementation of a diet from 0 to $4 \%$ tripled the ABC-4 value. For this reason, Bolduan et al. (1988) and Bolduan (1988) suggested limiting the mineral content of a starter diet for a short period postweaning. It was hypothesised that this practice would benefit the pigs in health terms. However, growth may be retarded to some extent by this practice as the mineral requirement for bone formation will not be supplied (Bolduan, 1988) especially if the period of restricted feeding of minerals is prolonged.

With regard to organic ingredients, their $A B C$ values are positively correlated with their ash and protein contents (Jasaitis et al., 1987; Bolduan et al., 1988; Bolduan, 1988). Prohaszka and Baron (1980) also found the $A B C-3$ of a feed to increase as its protein content increased. In the present experiment, meat and fishmeal had the highest $A B C$ and BUF values of all the organic ingredients. This was thought to be because of their high ash and protein contents. Jasaitis et al. (1987) also found these ingredients to have the highest $A B C-4$ values of all organic ingredients. The milk products category (in particular, rennet casein and spray dried skim) also had high $A B C$ values. However, the other ingredients in this category had lower values. Again, this is believed to be related to the ash and protein contents.

Of the vegetable proteins, soyabean meal, Soycomil, rapeseed, and sunflower meal had the highest $A B C$ values. Jasaitis et al. (1987) found that the geographic origin of an ingredient can affect its $A B C$ because it influences the ion concentration of the ingredient and this may help to explain the variation in $A B C$ values found for individual ingredients. Maize gluten and milo distillers meal were uncharacteristic of the vegetable protein group of ingredients in that they both had $\mathrm{pH}$ values less than 4.5 and their $A B C$ values were low relative to the other ingredients in this group. Jasaitis et al. (1987) also found such fermented products to have some of the lowest $A B C-4$ values of the organic ingredients examined.

Cereals and some root and pulp products had low $A B C$ and BUF values in the present experiment. This was in agreement with previous findings (Jasaitis et al., 1987; Bolduan, 1988; Bolduan et al., 1988 and BASF, 1989).

Acids were found to have negative $A B C$ values. The use of organic acids in starter diets offers the opportunity of lowering diet $A B C$ without having to reduce dietary protein or mineral content. However, the beneficial effects of organic acids on pig health are strongly dependent on the initial BUF value of the diet (Blank et al., 200I). The organic acids of choice would be orthophosphoric, fumaric, formic or malic if the prime mode of action of these acids was deemed to be the lowering of diet $A B C$ and increasing gastric acidity. However, acids for use in pig diets are often selected for other qualities also such as: antimicrobial effects on pathogenic bacteria, promotion of beneficial or probiotic bacteria, nutritional value, improved nonspecific immunity (Pratt et al., 1996), stimulatory effect on pancreatic secretion (e.g., lactic acid: Thaela et al., 1998), physical form (dry or liquid), corrosive nature and safety.

In the literature, $A B C-3$ values were used by some researchers (Prohaszka and Baron, 1980) while ABC-4 values were used by others (Jasaitis et al., 1987; Bolduan et al., 1988). The present study found that these values for ingredients are well correlated within ingredient

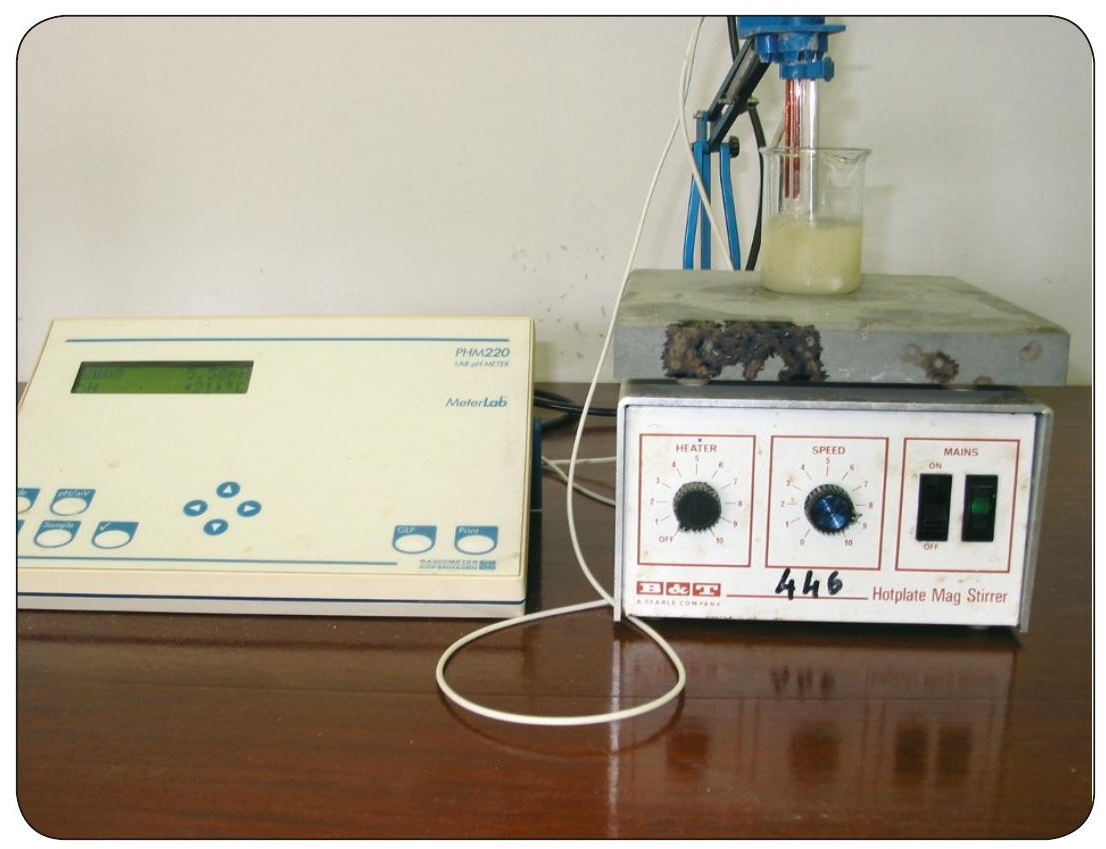

The $\mathrm{pH}$ and acid-binding capacity of ingredients commonly used in post-weaning pig diets was measured.

categories with the exception of acids and acid salts. For this reason, it should matter little which measure is used. Great variation occurred within ingredient categories with regard to $A B C$ and $B U F$ values.

The $A B C$ values of complete diets can be predicted if the $A B C$ of each ingredient in the diet is known. The observed and predicted $A B C$ values were well correlated. Jasaitis et al. (1987) also found this to be the case. The result is that diets can be formulated using the $A B C$ values for ingredients presented here so that complete diets with low $A B C$ values are produced. Such diets can be used when a high gastric $\mathrm{pH}$ is likely to be a problem (e.g., at weaning). These diets could also be employed as part of a strategy to reduce E. coli or Salmonella in older pigs. This is particularly important now due to recent EU bans on feed antibiotics in response to human fears of antibiotic resistant bacteria originating in animals (Barton, 2000; Bager et al., 2000).

\section{Acknowledgements}

The authors acknowledge the assistance of graduate students and work study students in performing the titrations recorded here. The provision of ingredient samples by Glanbia, Portlaoise and Dairygold, Mitchelstown is gratefully acknowledged.

\section{References}

Bager, F., Aarestrup, F.M. and Wegener, H.C. (2000). Dealing with antimicrobial resistance - the Danish experience. Canadian Journal of Animal Science 80: 223-228.

Barton, M.D. (2000). Antibiotic use in animal feed and its impact on human health. Nutrition Research Reviews 13: 279-299.

BASF (1989). The acid-binding capacity of piglets. Info-Service Animal Nutrition, BASF Aktiengesellschaft, D-6700, Ludwigshafen.

Blank, R., Sauer, W.C., Mosenthin, R., Zentek, J., Huang, S. and Roth, S. (200I). Effect of fumaric acid supplementation and dietary buffering capacity on the concentration of microbial metabolites in ileal digesta of young pigs. Canadian Journal of Animal Science 8I: 345-353. 
Bolduan, G. (1988). The regulation of the intestinal flora in piglets and sows - a new feeding strategy. In: From Research and Practical Experience No. 23. pp I-17. Ludwigshafen: BASF.

Bolduan, G., Jung, H., Schnabel, E. and Schneider, R. (1988). Recent advances in the nutrition of weaner pigs. Pig News and Information 9: 38I-385.

Cranwell, P.D. (1985). The development of acid and pepsin secretory capacity in the pig. The effects of age and weaning. I. Studies in anaesthetized pigs. British Journal of Nutrition 54: 305-320.

Cranwell, P.D. and Moughan, P.J. (1989). Biological limitations imposed by the digestive system to the growth performance of weaned pigs. In: Manipulating Pig Production II, PP 140-I59. Edited by J.L. Barnett and D.P. Hennessy. Werribee, Victoria, Australia: Australian Pig Science Association.

Cranwell, P.D., Noakes D.E. and Hill, K.J. (1968). Observations on the stomach content of the suckling pig. Proceedings of the Nutrition Society 27: 26A.

Cranwell, P.D., Noakes, D.E. and Hill, K.J. (1976). Gastric secretion and fermentation in the suckling pig. British Journal of Nutrition 36: 7I-86.

Easter, R.A. (1988). Acidification of diets for pigs. In: Recent Advances in Animal Nutrition, PP 6I-7I. Edited by D.J.A. Cole and W. Haresign. London: Butterworths.

Giger-Reverdin, S., Duvaux-Ponter, C., Sauvant, D., Martin, O., Nunes do Prado, I. and Miller, R. (2002). Intrinsic buffering capacity of feedstuffs. Animal Feed Science and Technology 96: 83-102.

Jasaitis, D.K., Wohlt, J.E. and Evans, J.L. (1987). Influence of feedion content on buffering capacity of ruminant feedstuffs in vitro. Journal of Dairy Science 70: 1391-1403.
Kidder, D.E. and Manners M.J. (1978). Digestion in the Pig. Bristol: Scientechnica.

Lawlor, P.G., Lynch, P.B., Caffrey, P. J. and O' Doherty, J.V. (2002). Effect of pre- and post-weaning management on subsequent pig performance to slaughter and carcass quality. Animal Science $\mathbf{7 5}$ 245-256.

Lawlor, P.G., Lynch, P.B. and Caffrey, P. J. (2005a). Effect of creep feeding, dietary fumaric acid and level of dairy product in the diet on post-weaning pig performance. (In press).

Lawlor, P.G., Lynch, P.B. and Caffrey, P. J. (2005b). Comparison of fumaric acid, calcium formate and mineral levels in diets for newly weaned pigs. Irish Journal of Agricultural and Food Research (unpublished data).

Longland, A.C. (1991). Digestive enzyme activities in pigs and poultry. In: In vitro Digestion for Pigs and Poultry, Pp 3-18. Edited by M.F. Fuller. Wallingford, U.K: CAB International.

Pratt, V.C., Tappenden, K.A., McBurney, M.I. and Field, C.J. (1996). Short chain fatty acid-supplemented total parenteral nutrition improves nonspecific immunity after intestinal resection in rats. Journal of Parenteral and Enteral Nutrition 20: 264-27I.

Prohaszka, L. and Baron, F. (1980). The predisposing role of high dietary protein supplies in enteropathogenic $E$. coli infections of weaned pigs. Zentralblatt für Veterinärmedicin 27: 222-232.

Thaela, M.J., Jensen, M.S., Pierzynowski, S.G., Jakob, S. and Jensen, B.B. (1998). Effect of lactic acid supplementation on pancreatic secretion in pigs after weaning. Journal of Animal and Feed Sciences 7 (supplement I): 181-183.

Yen, J.T. (200I). Anatomy of the digestive system and nutritional physiology. In: Swine Nutrition. Second edition, PP 3 I-63. Edited by A.J. Lewis and L.L. Southern. Boca Raton: CRC Press. 